\title{
The Effect of Positive Affirmations to Anxiety level and 2nd stage of labor length
}

\author{
Esty Puji Rahayu1*, Lailatul Khusnul Rizki \\ Universitas Nahdlatul Ulama Surabaya, Indonesia \\ *esty@unusa.ac.id
}

\begin{abstract}
Normal birthing is the process of labor which occurs naturally in the contractions of the mother's uterus and is followed by an opening to expel the baby. During this delivery period, complications are prone to occur that can lead to maternal death. Meanwhile, based on the 2017 Indonesian Demographic and Health Survey (IDHS), the average MMR reached 305 / 100,000 live births. The maternal mortality rate by sectio caesarea was $40-80$ per 100,000 live births, this figure indicates a 25 times greater risk and risk of infection. 80 times higher than vaginal labor. Secto Cesarean can occur because the mother herself is not sure of her ability to normal birthing. Positive affirmations made by mothers are believed to be one of the supports so that mothers are sure that they can give birth normally and reduce anxiety about childbirth. This type of research is observational analytic with a quasi-experimental design, the type of post test only group design. Researchers began to give affirmation cards to respondents starting at 36 weeks of gestation and followed by their progress until the labor process so that data on anxiety and length of time 2 during labor could be obtained by simple random sampling. The research instrument used affirmation flashcards, while anxiety used the Visual Analog Anxiety of Pain Scale (VAAPS) and the second stage of labor used the observation sheet. Data analysis used T test for each variable. Based on the results of data analysis with the $\mathrm{T}$ test, it was found that there was an effect of giving Positive affirmation on anxiety and $2^{\text {nd }}$ stage of labor with $p=0.000(p<0.05)$. Positive affirmation with flashcard affirmation media greatly affects the level of anxiety of mothers in labor and it is easier to self-affirm so that negative thoughts about childbirth will be reduced. The readiness of mothers in facing childbirth is an important point for smooth birthing. Maintaining the mother's psychological condition can be done by giving positive affirmations to the mother, besides that the support of husband and family is also an important point.
\end{abstract}

Keywords : Positive Affirmation, Anxiety, $2^{\text {nd }}$ Stage of Labor 


\section{STRADA Jurnal Ilmiah Kesehatan}

DOI: $10.30994 /$ sjik.v9i2.398

ISSN: 2252-3847 (print); 2614-350X (online)

Vol.9 No.2 November 2020 Page.900-905

\section{BACKGROUND}

Normal birthing is the process of labor which occurs naturally in the contractions of the mother's uterus and is followed by an opening to expel the baby. During this delivery period is prone to complications that can cause maternal death. The Sustainable Development Goals (SDGs) which were set in 2015 to 2030, Indonesia has an MMR target of up to $70 / 100,000 \mathrm{KH}$ and AKB 12/1000 KH (Dinkes, 2015). Meanwhile, based on the 2017 Indonesian Demographic and Health Survey (IDHS), the average IMR was recorded at 24 per 1000 live births. Meanwhile, MMR reached 305 / 100,000 live births (SUPAS, 2015). Meanwhile, in East Java, the MMR reached 90.2 per 100,000 live births, while the IMR was 20.1 / 1000 life skills (Dinkes Jatim, 2017).

Maternal mortality can also be caused by Sectio cesarean (SC). The maternal mortality rate by sectio caesarean is $40-80$ per 100,000 live births, this figure shows a 25 times greater risk and 80 times higher risk of infection than vaginal delivery (Suhartatik, 2014). Meanwhile, in the 2013 Riskesdas data analysis, it is known that mothers who have the opportunity to give birth by caesarean section are those who live in cities, with higher education levels, namely D3 / tertiary education graduates, economic status is in the highest quantile ownership (upper economy) and work in the formal sector as private employees (Sihombing, 2017). Sectio Cesarean can occur because the mother herself is not sure of her ability to normally labor smoothly. Positive affirmations made by mothers are believed to be one of the supports so that mothers are sure that they can give birth normally and reduce anxiety in facing childbirth

The psychological changes that occur in pregnant women are caused by the mother feeling anxious, worried that the baby is not normal and the mother is afraid in facing the labor process. The third trimester of the mother will experience a period of discouragement and depression due to increased discomfort and the mother will experience fear of safety during childbirth. Positive affirmation technique is a relaxation technique that can handle discomfort problems in pregnant women. Affirmative relaxation is a combination of deep breath relaxation and positive affirmations (Prawirohardjo, 2009).

The phenomenon in several areas of health service practice, not a few mothers giving birth screaming and feeling confused about the labor process they are experiencing, and generally health care providers think that it is common to every mother giving birth (Sariati, 2016). Uncontrolled emotional will affect the mother's anxiety in facing childbirth. Anxiety is a subjective feeling experienced by individuals. The psychosocial reactions of mothers who are about to give birth include feelings of anxiety, fear, and increased pain sensitivity.

Self-affirmation will reduce the mother's anxiety in dealing with childbirth. For this reason, the technique of reducing pain during labor needs to be mastered by midwives to put more emphasis on giving birth in a positive, gentle, safe way and how to achieve it easily (Aprilia, 2010). Affirmations are complete positive sentences that are compiled according to our wishes (for example when we do self hypnosis), are specific and contain hopes or ideals, the affirmations that are conveyed are not in a hypnotic state, they are merely informational. Affirmations can be used in a number of ways, can be pronounced / said aloud, written in a journal / diary or written on a card that you can see and can easily see in any place that is often seen everyday (on the dresser, on the door of the room, in office desks etc (Aprilia, 2019). 


\section{STRADA Jurnal Ilmiah Kesehatan}

DOI: $10.30994 /$ sjik.v9i2.398

ISSN: 2252-3847 (print); 2614-350X (online)

Vol.9 No.2 November 2020 Page.900-905

\section{METHOD}

The type of research used is observational analytic with a quasi-experimental design, post test only group design, which compares anxiety and $2^{\text {nd }}$ stage of labor lenght mothers who are given positive affirmation therapy and those who are not given affirmations. Then analyze the correlation between variables. This research was conducted using a longitudinal approach in which the researcher began to give affirmation cards to respondents starting at 36 weeks of gestation and followed by their progress until the delivery process so that data on anxiety and duration of $2^{\text {nd }}$ stage of labor be obtained. The sampling technique used simple random sampling. This research was conducted at PMB Mei Kurniawati, Amd.Keb. Research instruments for affirmation variables researchers used affirmation flashcards given to respondents. Meanwhile, anxiety uses the Visual Analog Anxiety Of Pain Scale (VAAPS) and the second stage of labor uses the observation sheet. Data obtained directly / primary data, data collection is done by filling out the observation sheet and recapitulating it. Data analysis used $\mathrm{T}$ test for each variable.

\section{RESULT}

The subjects in this study were 30 pregnant women with gestational age above 36 weeks. There were 15 pregnant women who were given treatment to read affirmation flashcards and 15 others as control variables who were not treated to read affirmation cards. The following are the results of the data obtained from research respondents:

Table 1. Subject characteristic based on age group

\begin{tabular}{lcccc}
\hline Age Group & \multicolumn{2}{c}{ Frequency $(\mathbf{n})$} & \multicolumn{2}{c}{ Percentage $(\%)$} \\
\cline { 2 - 5 } & treatment & kontrol & treatment & control \\
\hline < 20 years old & 1 & 1 & 6.67 & 6.67 \\
\hline $\mathbf{2 0}-\mathbf{2 5}$ years old & 1 & 2 & 6.67 & 13.33 \\
\hline $\mathbf{2 6}-\mathbf{3 0}$ years old & 5 & 6 & 33.33 & 40 \\
\hline $\mathbf{3 1}-\mathbf{3 5}$ years old & 7 & 3 & 46.66 & 20 \\
\hline $\mathbf{>} \mathbf{3 6}$ years old & 1 & 3 & 6.67 & 20 \\
\hline Total & 15 & 15 & 100 & 100 \\
\hline
\end{tabular}

Table 2. Subject characteristic based on paritas

\begin{tabular}{lcccc}
\hline Paritas & \multicolumn{2}{c}{ Frequency (n) } & \multicolumn{2}{c}{ Percentage (\%) } \\
\cline { 2 - 5 } & treatment & kontrol & treatment & control \\
\hline primipara & 4 & 1 & 26.67 & 6.67 \\
\hline multipara & 11 & 13 & 73.33 & 86.66 \\
\hline Grande multipara & 0 & 1 & 0 & 6.67 \\
\hline total & 15 & 15 & 100 & 100 \\
\hline
\end{tabular}

Table 3. Subject characteristic based on anxiety

\begin{tabular}{lcccc}
\hline Paritas & \multicolumn{2}{c}{ Frequency (n) } & \multicolumn{2}{c}{ Percentage (\%) } \\
\cline { 2 - 5 } & treatment & kontrol & treatment & control \\
\hline Mild anxiety & 11 & 6 & 73.33 & 40 \\
\hline Moderate anxiety & 3 & 9 & 20 & 60 \\
\hline Severe anxiety & 1 & 0 & 6.67 & 0 \\
\hline total & 15 & 15 & 100 & 100 \\
\hline
\end{tabular}




\section{STRADA Jurnal Ilmiah Kesehatan}

DOI: $10.30994 /$ sjik.v9i2.398

ISSN: 2252-3847 (print); 2614-350X (online)

Vol.9 No.2 November 2020 Page.900-905

Table 4. Subject characteristic based on $2^{\text {nd }}$ stage of labor

\begin{tabular}{lcccc}
\hline Paritas & \multicolumn{2}{c}{ Frequency (n) } & \multicolumn{2}{c}{ Percentage (\%) } \\
\cline { 2 - 5 } & treatment & kontrol & treatment & control \\
\hline$\leq \mathbf{5}$ minutes & 4 & 4 & 26.67 & 26.67 \\
\hline $\mathbf{6 - 1 0}$ minutes & 7 & 6 & 46.66 & 40 \\
\hline $\mathbf{1 1 - 1 5}$ minutes & 4 & 4 & 26.67 & 26.6 \\
\hline $\mathbf{1 6 - 2 0}$ minutes & 0 & 1 & 0 & 6.67 \\
\hline total & 15 & 15 & 100 & 100 \\
\hline
\end{tabular}

Based on the results of data analysis with the $T$ test on each variable, it was found that there was an effect of affirmation therapy on anxiety and 2 times duration with $\mathrm{p}$ $=0.000(\mathrm{p}<0.05)$. Affirmation was given by respondent reading the affirmation flashcard and the anxiety variable was obtained by using the VAAPS questionnaire.

\section{DISCUSSION}

\section{Effect of positive affirmations on anxiety during childbirth}

Anxiety is a universal human experience and a feeling that is not expressed because of a source of threat or thoughts that are not clear and unidentified, anxiety is closely related to feelings of uncertainty and helplessness characterized by feelings of deep fear or worry. causing anxiety of pregnant women before childbirth, including age, knowledge of childbirth, parity and pregnancy checks (Manuaba, 2010).

For mothers who have given birth for the first time, there is no idea about what will happen during childbirth and are afraid because they often hear terrible stories from friends or relatives about experiences during childbirth such as the mother or the baby dies and this will affect the mother's mindset regarding the frightening labor process. In this study, the most respondents were multiparous mothers where the number of children was 2-4 people, namely $73.33 \%$ in the treatment group and $86.66 \%$ in the control group.

Many things have been done to reduce anxiety in the facing childbirth. Pregnancy exercise as a prenatal service is effective in reducing anxiety in facing the first labor (Wulandari, 2006). Apart from that, anxiety in dealing with childbirthing can also be reduced by breathing relaxation techniques. This technique can be used as an alternative to the first choice to reduce anxiety in pregnant women because it is easy to implement and can be done independently and sustainably at home (Laili, 2017).

In addition to pregnancy exercise and breathing relaxation, positive affirmations can also reduce anxiety. In this study the respondents were divided into 2 groups, namely the treatment group with flashcard affirmation and the control group without flashcard affirmation. In the treatment group the most was mild anxiety, namely as much as $73.33 \%$, while in the control group the most was moderate anxiety level, which was $60 \%$. From the data above, data analysis was carried out using the $T$ test. The results showed that there was a positive effect of affirmation on maternal anxiety in facing childbirth with $\mathrm{p}=0.000$ $(\mathrm{p}<0.05)$.

The results of this study are in line with research conducted by Indrayani, 2019 that there is a significant difference between the score of anxiety level before and after affirmation with $\mathrm{p} 0.00$ where the value is $(\mathrm{p} \leq 0.005)$, while for the control group the results of $t$ count are 0.000 and $p 1.000$, where with this value $(p \geq 0.005)$, there is no significant difference between anxiety scores 


\section{STRADA Jurnal Ilmiah Kesehatan}

DOI: $10.30994 /$ sjik.v9i2.398

ISSN: 2252-3847 (print); 2614-350X (online)

Vol.9 No.2 November 2020 Page.900-905

Affirmation is a form of self-affirmation related to positive things. Through these positive words, the brain will indirectly be indoctrinated so that our own perspective will also change. Affirmations can change a person's perspective in dealing with life and the environment around him. As a result, affirmations will make our minds more positive. Other benefits include growing self-confidence, improving body health, keeping away from depression, providing self-comfort, and making ourselves happier.

The assumption of the researchers was that giving affirmation using flashcard affirmation greatly influenced the level of anxiety of the mother in labor. With flashcard affirmation, it is easier for mothers to affirm themselves so that there will be less negative thoughts about childbirth. It is undeniable that during childbirth, all muscles contract, if this affirmation is carried out from pregnancy to before delivery, it can reduce pain and anxiety during childbirth. In addition, this anxiety will also be reduced if there is support from family and health workers, as well as a comfortable delivery place

\section{Effect positive affirmation on $2^{\text {nd }}$ stage of labor duration}

Childbirth is a frightening condition, especially for mothers who are experiencing labor for the first time. Preparations made during pregnancy have not been able to guarantee the mother to be ready for childbirth. Negative images are often complained of appearing in mothers near the time of delivery (Handayani, 2017).

Prolonged second stage labor is possible because of the anxiety conditions they face with the birth. Anxiety experienced by mothers in labor may occur because they are experiencing stress or it can also be caused by a lack of information received by mothers in dealing with childbirth. In this study, most respondents with positive affirmation treatment experienced stage 2 for 5-10 minutes (46.66\%), while in the control group most respondents experienced stage 2 for 5-10 minutes (40\%). However, in the control group there were respondents who experienced stage 2 for 16-20 minutes, while in the treatment group none experienced stage 2 for more than 16 minutes. Based on these data, the analysis results obtained with the $T$ test, namely $\mathrm{p}=0.000(\mathrm{p}<0.05)$, which means that there is a positive affirmative effect with $2^{\text {nd }}$ stage of labor duration.

Positive affirmations are part of hypnobirthing. The results of this study on the effect of positive affirmation with $2^{\text {nd }}$ stage of labor duration are in line with research conducted by Dona, 2016 with the results of the hypnobirthing method having a very significant effect on the length of the labor process $(\mathrm{p}<0.05)$, in mothers who received hypnobirthing treatment had time fewer labor processes compared to mothers who gave birth who were given loving care.

Researchers assume that many factors affect the smoothness and duration of labor, especially in second stage. Parity, age and psychological condition of the mother greatly affect the duration of second stage. Multiparity mothers are likely to have faster process of birthing. However, it cannot be denied that the readiness of the mother in facing childbirth is an important point for the smooth birthing. Keeping the mother's good psychological condition good can be done by giving positive affirmations to the mother, besides that the support of husband and family is also an equally important point

\section{CONCLUSION}

There is a significant effect of positive affirmation on anxiety and duration of 2 in mothers giving birth 


\section{STRADA Jurnal Ilmiah Kesehatan}

DOI: $10.30994 /$ sjik.v9i2.398

ISSN: 2252-3847 (print); 2614-350X (online)

Vol.9 No.2 November 2020 Page.900-905

\section{REFERENCES}

Aprilia,Yesie. 2017. \# Free are afraid of pregnancy and childbirth. Jakarta: Gramedia Dona, Sismeri. 2016. Difference in length of labor using hypnobirthing technique and without hypnobirthing technique. Dinamika Kesehatan Vol. 7 No. 2 Desember 2016

Handayani, R. (2017). Factors Related to Anxiety Levels Toward Delivery in Trimester III Primigravida Mother in the Work Area of Puskesmas Lubuk Buaya Padang in 2012.Ners Jurnal Keperawatan,11(1), 60-69.

Hidayati, Tuti. 2019. The Influence of Family Support (Husband) with the Second Stage of Labor. Jurnal Keperawatan dan Kebidanan, Volume XI, Nomor 1, Februari 2019

Indriyani, Triyana. 2019. Affirmation Effectiveness of Health Workers on Anxiety Levels of Multiparous Maternity Mothers at Bula Regional Hospital, East Seram Regency in 2018/2019. Jurnal Ilmu dan Budaya Vol 41, No 63 (2019)

Manuaba, Ida Bagus Gde, 2010. Book of Obstetrics and Gynecology and Family Planning for Midwifery Education, 2nd Edition. Jakarta: EGC

Laili, Fuzia. 2016. The Effect of Deep Breath Relaxation Techniques on Anxiety in Facing Childbirth in Pregnant Women. Jurnal Kebidanan Vol 3, No 3, Juli 2017 : 152-156

Sihombing, Novianti. 2017. Determinants of Section Caesarean Delivery in Indonesia (Advanced Analysis of Riskesdas 2013 Data). Jurnal Kesehatan Reproduksi, 8(1), 2017: 63-75

Suhartatik. 2014. Factors that Affect Pregnant Women in Choosing a Caesarean Section Delivery. Jurnal Stikes Nani Hasanudin Makassar 